DOI: $10.19195 / 0137-1134.115 .6$

\author{
PAWEŁ LENIO \\ ORCID: 0000-0002-9364-7318 \\ Uniwersytet Wrocławski
}

\title{
ŹRÓDŁA FINANSOWANIA OCHRONY ZDROWIA W POLSCE I WE WŁOSZECH*
}

\begin{abstract}
Abstrakt: Opracowanie porusza problematykę zasad finansowania ochrony zdrowia w Polsce i we Włoszech. Celem było ustalenie różnic i podobieństw zachodzących między tymi systemami. Modele zdrowotne we wskazanych państwach Unii Europejskiej zasadniczo różnią się od siebie, co zostało wykazane w artykule. Można jednak zauważyć pewne podobieństwa zachodzące pomiędzy nimi. Opracowanie zawiera także postulaty de lege ferenda wynikające z porównania systemów finansowania opieki zdrowotnej w Polsce i we Włoszech.
\end{abstract}

Słowa kluczowe: ochrona zdrowia, finanse publiczne, systemy finansowania

\section{WPROWADZENIE}

W państwach Unii Europejskiej (dalej: UE) istnieją zróżnicowane systemy organizacji i finansowania ochrony zdrowia. Zdecydowana większość z nich funkcjonuje na podstawie pierwotnych modeli zdrowotnych, do których zalicza się model ubezpieczeniowy (model Bismarcka) i budżetowy (model Beveridge’a). Charakterystyczną cechą pierwszego $\mathrm{z}$ nich jest istnienie jednej lub wielu instytucji ubezpieczeniowych, których głównym celem jest zagwarantowanie osobom ubezpieczonym dostępu do świadczeń zdrowotnych przysługujących na wypadek wystąpienia ryzyka objętego ochroną ubezpieczeniową. Istotą modelu Beveridge'a jest natomiast zagwarantowanie świadczeń zdrowotnych wszystkim obywatelom. Uzyskanie świadczeń opieki zdrowotnej nie jest w nim uwarunkowane posiadaniem statusu osoby ubezpieczonej.

Katalog publicznoprawnych źródeł finansowania ochrony zdrowia jest determinowany przyjęciem określonego modelu organizacyjnego. W przypadku

* Opracowanie przygotowane w ramach projektu pt. „Źródła finansowania ochrony zdrowia w Polsce - aspekty prawne" finansowanego w konkursie PRELUDIUM 8 organizowanym przez Narodowe Centrum Nauki (nr projektu: 2014/15/N/HS5/01735). 
modelu ubezpieczeniowego głównym źródłem jego finansowania jest składka na ubezpieczenie zdrowotne, opłacana zasadniczo przez osoby ubezpieczone. Model Beveridge'a zapewnia świadczenia zdrowotne wszystkim obywatelom na podstawie wydatków z budżetu centralnego lub z budżetów właściwych jednostek samorządu terytorialnego.

Włoski system ochrony zdrowia wykorzystuje obecnie pierwotne założenia modelu Beveridge'a. Polskie regulacje prawne w tym zakresie opierają się na rozwiązaniach instytucjonalnych i finansowych modelu Bismarcka. W związku $\mathrm{z}$ tym uzasadnione wydaje się przeprowadzenie badań $\mathrm{w}$ przedmiocie ustalenia najistotniejszych różnic i podobieństw w zakresie źródeł finansowania ochrony zdrowia we wskazanych państwach.

\section{WŁOSKI SYSTEM OCHRONY ZDROWIA I ŹRÓDłA JEGO FINANSOWANIA}

Zasady funkcjonowania systemu ochrony zdrowia we Włoszech zostały ujęte w ustawie nr 833 z dnia 23 grudnia 1978 roku$^{1}$, która była wielokrotnie nowelizowana. Do najważniejszych aktów zmieniających system ochrony zdrowia należy zaliczyć dekret ustawodawczy z 1992 roku $^{2}$ (zmienił zasady gromadzenia i podziału środków przeznaczanych na realizację zadań publicznych z zakresu ochrony zdrowia), ustawę $\mathrm{nr} 662$ z 1996 roku $^{3}$, dekret ustawodawczy nr 446 z 1997 ro$\mathrm{ku}^{4}$ (zniósł obowiązkowe składki na finansowanie systemu) oraz dekret ustawodawczy nr 56 z 2000 roku$^{5}$ (przeniósł ciężar finansowania systemu zdrowotnego częściowo na regiony włoskie).

System ochrony zdrowia we Włoszech funkcjonuje na podstawie działalności Narodowej Służby Zdrowia (Servizio Sanitario Nazionale - SSN). Jego kształt jest efektem reform przeprowadzonych w ciągu kilku dekad. Obecnie funkcjonujący system istotnie odbiega od pierwotnie obowiązujących rozwiązań organizacyjnych i finansowych ${ }^{6}$. Główną rolę w jego funkcjonowaniu pełnią regiony włoskie i prowincje autonomiczne, a także lokalne jednostki terytorialne (odpowiedzialne za prowadzenie przedsiębiorstw służby zdrowia oraz szpitali). Zgodnie

${ }^{1}$ Legge del 23 dicembre 1978, n. 833; Gazzetta Ufficiale del 28 dicembre 1978, n. 360, dalej: ustawa 1978/833.

2 Decreto legislativo del 30 dicembre 1992, n. 502, Supplemento ordinario alla Gazzetta Ufficiale del 30 dicembre 1992, n. 305, dalej: dekret 1992/502.

3 Legge del 23 dicembre 1996, n. 662, Gazzetta Ufficiale del 28 dicembre 1996, n. 303, dalej: ustawa 1996/662.

4 Decreto legislativo del 15 dicembre 1997, n. 446, Gazzetta Ufficiale del 23 dicembre 1997, n. 298, dalej: dekret 1997/446.

5 Decreto legislativo del 18 febbraio 2000, n. 56, Gazzetta Ufficiale del 15 marzo 2000, n. 62.

6 B. Łyszczarz, System finansowania opieki zdrowotnej w krajach OECD, ,Studia Ekonomiczne — Zeszyty Naukowe" 2013, nr 145, s. 172. 
z art. 1 ustawy 1978/833 do zadań państwa i regionów, a także lokalnych jednostek terytorialnych (gmin) należy zagwarantowanie prawidłowego funkcjonowania Narodowej Służby Zdrowia.

Do kompetencji organów administracji rządowej zalicza się między innymi planowanie systemu ochrony zdrowia, ustalanie długoterminowych celów oraz kontrolę działalności Narodowej Służby Zdrowia ${ }^{7}$. Poza tym mogą one ustalać zakres oraz poziomy świadczeń zdrowotnych. Organy administracji rządowej odpowiadają także za finansowanie Narodowej Służby Zdrowia poprzez redystrybucję środków publicznych pomiędzy poszczególne regiony włoskie ${ }^{8}$. Regiony i prowincje włoskie wraz z organami administracji państwowej ponoszą wspólną odpowiedzialność za organizację i finansowanie Narodowej Służby Zdrowia. W literaturze włoskiej wskazuje się, że regiony zobowiązane są do organizacji i administrowania systemem ochrony zdrowia finansowanym ze środków publicznych, państwo zaś jest odpowiedzialne za zapewnienie obywatelom świadczeń zdrowotnych na terytorium całego kraju 9 .

Narodowa Służba Zdrowia we Włoszech jest zasadniczo finansowana ze środków publicznych pochodzących z budżetu państwa oraz budżetów włoskich jednostek samorządu terytorialnego. Organy administracji rządowej są natomiast zobowiązane do ustalenia źródeł finansowania systemu ochrony zdrowia ${ }^{10}$. Źródłem tym są także opłaty za niektóre rodzaje udzielanych świadczen ${ }^{11}$. Wysokość środków prywatnych przeznaczanych na finansowanie świadczeń zdrowotnych wynosi około $17,8 \%$ całości wydatków systemu ${ }^{12}$.

Główne znaczenie dla finansowania systemu ochrony zdrowia mają środki publiczne przekazane ustawowo do dyspozycji włoskim regionom, do których należy zaliczyć podatek regionalny od działalności produkcyjnej ${ }^{13}$, dodatek regionalny do podatku dochodowego od osób fizycznych ${ }^{14}$ oraz część wpływów z tytułu podatku od wartości dodanej ${ }^{15}$. W większości przypadków włoskim regionom

7 M. Tanner, The grass is not always greener. A look at Health Care Systems around the world. Italy, „Policy Analysis” 2008, nr 613, s. 12.

8 F. Ferre et al., Italy. Health system review, „Health System in Transition” 16, 2014, nr 4, s. 20 .

9 G. France, F. Taroni, A. Donatini, The Italian health-care system, „Health Economics” 2014, nr 14, s. $187-188$.

10 G. Cilione, Diritto sanitario. Profili constituzionali e amministrativi, ripartizione delle competenze, organizzazione, prestazioni, presidi sanitari privati, professioni, Rimini 2005, s. 265.

11 F. Reviglio, Health care and its financing in Italy: Issues and reform options, „IMF Working Paper" 2000, s. 6.

12 F. Ferre et al., op. cit., s. 41.

13 Imposta regionale sulle attività produttive, dalej: IRAP.

14 Imposta sul reddito delle persone fisiche, dalej: IRPEF.

15 F. Ferre et al., op. cit., s. 51; M. Urbaniak, Aspekty publicznoprawne organizacji i finansowania ochrony zdrowia w Republice Włoskiej, Torun 2014, s. 307. 
przekazano jedynie wpływy z poszczególnych danin publicznych. Regiony nie posiadają $\mathrm{w}$ tym zakresie władztwa daninowego.

Zgodnie z art. 63 ustawy 1978/833 w brzmieniu pierwotnym ochrona zdrowia była finansowana głównie $\mathrm{z}$ wpływów z tytułu pobierania składki ubezpieczeniowej. Wszyscy obywatele byli zobowiązani do uiszczania składek na ubezpieczenie zdrowotne. Na podstawie przepisów ustawy 1978/833 utworzono włoski Narodowy Fundusz Zdrowia, którego głównym dochodem były wpływy z tytułu składki zdrowotnej. Część dochodów Funduszu pochodziła także z ogólnych dochodów budżetu państwa ${ }^{16}$.

Na podstawie art. 11 dekretu 1992/502 wpływy z tytułu składek na ubezpieczenie zdrowotne przekazano na stałe włoskim regionom. Celem nałożenia na regiony włoskie obowiązków w zakresie ponoszenia kosztów finansowania systemu zdrowotnego było między innymi ograniczenie wydatków budżetu centralnego. Zostały one zobowiązane do współuczestnictwa w finansowaniu systemu ochrony zdrowia oraz ciążył na nich obowiązek pokrywania deficytu lokalnych jednostek ochrony zdrowia i szpitali.

Jako zasadniczą zmianę sposobu finansowania Narodowej Służby Zdrowia należy także wskazać wprowadzenie nowych zasad podziału środków publicznych pozostających w dyspozycji Narodowego Funduszu Zdrowia. W świetle przepisów dekretu 1992/502 Narodowa Służba Zdrowia miała być finansowana $\mathrm{z}$ budżetu państwa, składek na ubezpieczenie zdrowotne o charakterze obowiązkowym oraz środków prywatnych świadczeniobiorców pochodzących z uiszczanych przez nich opłat. Wysokość przekazywanych środków miała być każdorazowo ujmowana w budżecie państwa ${ }^{17}$.

Na przełomie XX i XXI wieku istotnie zreformowano Narodową Służbę Zdrowia. Na podstawie przepisów dekretu 1997/446 zlikwidowano składkę na ubezpieczenie zdrowotne. Skutkiem była konieczność zapewnienia dochodów przeznaczanych na finansowanie systemu ochrony zdrowia. Wprowadzono zatem podatek IRAP stanowiący źródło dochodów poszczególnych regionów włoskich ${ }^{18}$.

$\mathrm{Z}$ dniem 1 stycznia 2001 roku zrezygnowano także z bezpośredniego finansowania $z$ budżetu państwa wydatków regionów przeznaczanych na zapewnienie funkcjonowania Narodowej Służby Zdrowia. Spadek dochodów budżetowych regionów z tytułu wydatków budżetu państwa na ich rzecz zastąpiono głównie współudziałem regionów we wpływach z włoskiego podatku od wartości dodanej, wzrostem stawki podatku IRAP $(0,9 \%$ podstawy wymiaru z możliwością jej zwiększenia do $1,4 \%$ uzależnioną od autonomicznych decyzji poszczególnych

16 G. Turati, The Italian Servizio Sanitario Nazionale: A renewing tale of lost promises, [w:] Federalism and Decentralization in European Health and Social Care, red. J. Costa-Font, S. Greer, New York 2013, s. 50.

17 M. Urbaniak, op. cit., s. 298-299.

18 C. Palladino, Ordinamento sanitario. Disciplina del Servizio sanitario nazionale, Napoli 2012, s. 119. 
regionów), a także współudziałem regionów we wpływach z tytułu pobieranej $\operatorname{akcyzy}^{19}$.

Włoski ustawodawca nie zrezygnował jednak definitywnie $\mathrm{z}$ finansowania systemu ochrony zdrowia ze środków pochodzących z budżetu państwa. Są one w dalszym ciągu przeznaczane na pokrycie wydatków Narodowej Służby Zdrowia, mimo że odpowiedzialność za jej działalność przeniesiono na poszczególne regiony. Ze środków budżetu państwa finansowane są przede wszystkim świadczenia zdrowotne dla emigrantów, leczenie ustawowo wskazanych chorób oraz inwestycje przedsiębiorstw szpitalnych. Dokonano także likwidacji Narodowego Funduszu Zdrowia (art. 1 dekretu 2000/56). Skutkiem było wprowadzenie systemu finansowania Narodowej Służby Zdrowia opartego na zdolności dochodowej (podatkowej) danego regionu.

Sposób obliczania wysokości środków publicznych wydatkowanych na ochronę zdrowia na podstawie historycznych kosztów zastąpiono zasadami obliczania środków wydatkowanych na ochronę zdrowia opartymi na faktycznie ponoszonych kosztach świadczeń. Jako kryteria stanowiące podstawę ustalania wysokości niezbędnych wydatków przyjęto: liczbę ludności, wysokość dochodów z tytułu podatków regionalnych oraz zapotrzebowanie na świadczenia zdrowotne, a także powierzchnię regionu ${ }^{20}$. W myśl dekretu $\mathrm{nr} 68 \mathrm{z} 2011$ roku $^{21}$ standardowe potrzeby regionów miały być ustalane na podstawie kosztów rozsądnie wymaganych celem zapewnienia poszczególnych świadczeń zdrowotnych.

Występujący często deficyt $\mathrm{w}$ regionalnych systemach ochrony zdrowia wymagał wprowadzania nowych rozwiązań. Na podstawie układów zawartych pomiędzy rządem a regionami i włoskimi prowincjami autonomicznymi deficyt Narodowej Służby Zdrowia miał być w znacznej części pokrywany z budżetów regionów, na przykład poprzez podniesienie stawek podatku IRAP oraz regionalnego podatku dochodowego do najwyższego poziomu wynikającego z obowiązujących przepisów. Tego rodzaju działania miały być dokonywane w ramach planu wyrównawczego, który skutkował możliwością pozyskania środków z budżetu państwa ${ }^{22}$. Wynika z tego, że włoski ustawodawca dąży do przeniesienia na regiony znacznie większej odpowiedzialności za funkcjonowanie gospodarki finansowej w sektorze ochrony zdrowia. Odpowiedzialność polityczną przed obywatelami w zakresie zwiększania stawek podatkowych w celu finansowania deficytu ponoszą bowiem regiony włoskie, a nie organy administracji rządowej ${ }^{23}$.

19 Ibidem, s. 120.

20 N. Dirindin, Federalismo fiscale e tutela della salute. Un percorso di responsabilizzazione della regioni o il pressuposto pre cambiementi strutturali?, [w:] N. Dirindin, E. Pagano, Governare il federalismo. Le sfide della sanità, Milano 2001, s. 7 n.

21 Decreto legislativo del 6 maggio 2011, n. 68, Gazzetta Ufficiale del 12.05.2011, n. 109.

22 C. Palladino, op. cit., s. 123-124.

23 Ibidem, s. 124. 
Wprowadzenie finansowania przez regiony wydatków przeznaczanych na zadania Narodowej Służby Zdrowia, w tym występującego jej deficytu, spotkało się z ich sprzeciwem. Skutkiem są liczne orzeczenia Sądu Konstytucyjnego Republiki Włoskiej w przedmiocie zgodności wprowadzanych regulacji z Konstytucją Republiki Włoskiej. Sąd stwierdził, że nie jest możliwe przypisanie odpowiedzialności za gospodarkę finansową Narodowej Służby Zdrowia na poziomie poszczególnych regionów. Wynika to bowiem z faktu, że w znacznej części „zarówno świadczenia, które regiony powinny zapewnić na jednolitym poziomie na całym terytorium państwa, jak i odpowiedni poziom finansowania, są przedmiotem negocjacji między państwem a regionami" ${ }^{24}$. Zdaniem Sądu regiony mają możliwość pokrycia powstałego deficytu z własnych środków. W literaturze prawa włoskiego twierdzi się natomiast, że możliwość pokrycia deficytu ze środków pozostających w dyspozycji regionu ma jedynie charakter teoretyczny. Możliwości pozyskiwania we własnym zakresie wyższych dochodów budżetowych przeznaczanych na finansowanie ochrony zdrowia mają bowiem ograniczony charakter. Regiony mogą jedynie zwiększać stawki niektórych podatków oraz zwiększyć formy współuczestniczenia świadczeniobiorców w finansowaniu Narodowej Służby Zdrowia ${ }^{25}$.

\section{2. ŹRÓDŁA FINANSOWANIA OCHRONY ZDROWIA W POLSCE}

Zasady organizacji i finansowania funkcjonującego obecnie w Polsce systemu ochrony zdrowia wynikają co najmniej z kilku aktów prawnych rangi ustawowej, to jest z ustawy o świadczeniach opieki zdrowotnej finansowanych ze środków publicznych ${ }^{26}$ oraz ustawy o działalności leczniczej ${ }^{27}$, a także w zakresie prawnofinansowych aspektów wydatkowania środków publicznych z ustawy o finansach publicznych $^{28}$.

Z przepisów ustawy o świadczeniach opieki zdrowotnej finansowanych ze środków publicznych wynika, że polski system ochrony zdrowia został oparty na powszechnym obowiązkowym i dobrowolnym ubezpieczeniu zdrowotnym. Instytucją zarządzającą ubezpieczeniem zdrowotnym jest Narodowy Fundusz Zdrowia

${ }^{24}$ Orzeczenie Sądu Konstytucyjnego Republiki Włoskiej nr 98 z dnia 27 marca 2007 roku; Gazzetta Ufficiale Serie Speciale - Corte Costituzionale numer 13 z dnia 28 marca 2007 roku.

25 E. Innocenti, Il finanziamento della spesa sanitaria nella recente giurisprudenza costituzionale: tra tutela della salute, coordinamento della finanza pubblica e (in)attuazione dell' art. 119 Cost., „Le Regioni” 2008, nr 36, s. 583.

26 Ustawa z dnia 27 sierpnia 2004 roku o świadczeniach opieki zdrowotnej finansowanych ze środków publicznych, Dz.U. z 2016 r. poz. 1793 ze zm., dalej: u.ś.o.z.

27 Ustawa z dnia 15 kwietnia 2011 roku o działalności leczniczej, Dz.U. z 2013 r. poz. 217 ze zm., dalej również: u.d.l.

28 Ustawa z dnia 27 sierpnia 2009 roku o finansach publicznych, Dz.U. z 2016 r. poz. 1870 ze zm., dalej również: u.f.p. 
(dalej również: Fundusz lub NFZ) będący państwową jednostką organizacyjną posiadającą osobowość prawną. W myśl art. 97 u.ś.o.z. Fundusz zarządza środkami publicznymi pochodzącymi przede wszystkim z opłacanych przez ubezpieczonych składek oraz dotacji udzielanych z budżetu państwa na realizację niektórych zadań z zakresu ochrony zdrowia. Do zadań NFZ należy przede wszystkim określanie jakości i dostępności oraz analiza kosztów świadczeń opieki zdrowotnej w zakresie niezbędnym do prawidłowego zawierania umów o udzielanie świadczeń opieki zdrowotnej, przeprowadzanie konkursów ofert, rokowań i zawieranie umów o udzielanie świadczeń opieki zdrowotnej, a także finansowanie świadczeń zdrowotnych osobom niemającym statusu ubezpieczonego (art. 97 ust. 3 u.ś.o.z.).

Główny źródłem finansowania systemu jest składka na ubezpieczenie zdrowotne. W planie finansowym Narodowego Funduszu Zdrowia na rok 2017 przychody z jej tytułu mają wynieść ponad $73 \mathrm{mld} \mathrm{zł29}$. Jak już ustalono, składka na ubezpieczenie zdrowotne stanowi źródło finansowania ochrony zdrowia we Włoszech jedyne w aspekcie historycznym. W związku z tym nie będzie ona przedmiotem analizy niniejszego opracowania ${ }^{30}$.

Drugim, obok składki na ubezpieczenie zdrowotne, źródłem finansowania ochrony zdrowia w Polsce są budżety jednostek samorządu terytorialnego (dalej również: j.s.t.). Finansowane są z nich zadania własne samorządu z zakresu ochrony zdrowia. Wydatki budżetów samorządowych w tym zakresie można podzielić na: wydatki związane $\mathrm{z}$ finansowaniem zadłużenia samodzielnych publicznych zakładów opieki zdrowotnej (dalej również: s.p.z.o.z. lub zakłady), wydatki majątkowe związane z tworzeniem podmiotów leczniczych w formie spółek kapitałowych oraz wydatki na finansowanie działalności wykonywanej przez podmioty prowadzące działalność leczniczą. Od dnia 15 lipca 2016 roku j.s.t. mogą także dokonywać wydatków budżetowych w celu finansowania gwarantowanych świadczeń zdrowotnych. Jest to zadanie j.s.t. o charakterze fakultatywnym. Zgodnie z art. 9a u.ś.o.z. w celu zaspokajania potrzeb wspólnoty samorządowej w zakresie ochrony zdrowia j.s.t., uwzględniając w szczególności regionalną mapę potrzeb zdrowotnych, priorytety regionalnej polityki zdrowotnej oraz stan dostępności świadczeń opieki zdrowotnej na obszarze województwa, mogą finansować mieszkańcom tej wspólnoty świadczenia gwarantowane.

Jednostki samorządu terytorialnego mogą tworzyć i prowadzić podmioty lecznicze między innymi w formie s.p.z.o.z. oraz w formie spółek kapitałowych

29 Roczny plan finansowy Narodowego Funduszu Zdrowia na rok 2017, http://www.nfz.gov. pl/bip/finanse-nfz (dostęp: 14.09.2017).

30 Problematyka składki zdrowotnej została przeze mnie przedstawiona m.in. w opracowaniach: P. Lenio, Charakter prawny składki na ubezpieczenie zdrowotne jako źródła finansowania świadczeń opieki zdrowotnej, „Przegląd Prawa i Administracji” 2014, nr 97, s. 99-115; idem, Ulgi w zapłacie składki zdrowotnej dla przedsiębiorców, „Prawo Budżetowe Państwa i Samorządu” 2014, nr 2, s. 101-113; idem, Health insurance contributions of farmers, [w:] Essential problems with taxation of agriculture, red. M. Burzec, P. Smoleń, Lublin 2017, s. 399-412. 
(art. 6 ust. 2 u.d.1.) $)^{31}$. Poszczególne j.s.t., które są podmiotami tworzącymi zakładów tego rodzaju, są zobowiązane do dokonywania wydatków w celu sfinansowania zadłużenia $\mathrm{w}$ przypadku powstania straty netto ${ }^{32}$ i niepokrycia jej we własnym zakresie przez s.p.z.o.z., chyba że j.s.t. podejmie decyzję o likwidacji zakładu. Drugim rodzajem wydatku w przypadku powstania zadłużenia s.p.z.o.z. jest finansowanie jego zobowiązań w związku z likwidacją bądź przekształceniem (art. 61 i 72 u.d.1.). Tego rodzaju wydatki budżetów samorządowych mają istotne znaczenie ekonomiczne i prawne. Wysokość zadłużenia zakładów, dla których podmiotami tworzącymi są j.s.t., wynosi obecnie około 7-8 mld zł33. Gminy, powiaty i województwa samorządowe mają także możliwość tworzenia i przystępowania do podmiotów leczniczych działających w formie spółki z ograniczoną odpowiedzialnością lub spółki akcyjnej. Wydatki j.s.t. dotyczące funkcjonowania spółki, której są akcjonariuszem bądź udziałowcem, dotyczą głównie zakupu i objęcia akcji i udziałów oraz wniesienia wkładów, o których mowa w art. 236 ust. 4 pkt 2 i 3 u.f.p.

Z budżetów samorządowych mogą być finansowane wydatki przeznaczane na zadania z zakresu ochrony zdrowia dokonywane w prawnej formie dotacji celowej, której zasady udzielania wynikają z art. 114 i 115 u.d., oraz na podstawie umowy, o której mowa w art. 116 ust. 1 u.d.l. Mogą one być przeznaczane na określone zadania z zakresu ochrony zdrowia wykonywane przez wszystkie podmioty prowadzące działalność leczniczą, między innymi na realizację zadań w zakresie programów polityki zdrowotnej, programów zdrowotnych i promocji zdrowia, w tym zakup aparatury i sprzętu medycznego, oraz inwestycje konieczne do realizacji tych zadań, a także na remonty, inne niż wyżej wskazane inwestycje, w tym zakup aparatury i sprzętu medycznego.

Trzecim istotnym publicznoprawnym źródłem finansowania ochrony zdrowia w Polsce jest budżet państwa. W świetle obowiązujących przepisów organy administracji rządowej mogą przede wszystkim tworzyć i prowadzić podmioty lecznicze działające głównie w formie spółek kapitałowych bądź s.p.z.o.z. Organy administracji rządowej są również zobowiązane do finansowania niektórych świadczeń zdrowotnych, za których udzielanie odpowiedzialny jest Fundusz. Z punktu widzenia wydatkowania środków publicznych na tych organach ciążą

31 Jednostki samorządu terytorialnego mogą także tworzyć podmioty lecznicze w formie jednostek budżetowych (art. 6 ust. 2 pkt 3 u.d.l.). Tego rodzaju forma prawna prowadzenia działalności leczniczej nie jest jednak powszechnie wykorzystywana przez j.s.t., a także przez organy reprezentujące Skarb Państwa.

$32 \mathrm{~W}$ poprzednim stanie prawnym ustawodawca posługiwał się terminem ujemnego wyniku finansowego.

33 Najwyższa Izba Kontroli (delegatura w Opolu), Restrukturyzacja wybranych samodzielnych publicznych zakładów opieki zdrowotnej korzystajacych z pomocy ze środków publicznych (informacja o wynikach kontroli), www.nik.gov.pl https:/www.nik.gov.pl/kontrole/P/15/092/ (dostęp: 15.09.2017).

Przegląd Prawa i Administracji 115, 2018

(C) for this edition by CNS 
istotne obowiązki związane z organizacją i finansowaniem Państwowego Ratownictwa Medycznego.

Zakres nałożonych obowiązków powoduje konieczność wydatkowania środków publicznych pochodzących z budżetu państwa, które pozostają w dyspozycji poszczególnych organów. W związku z tym z budżetu centralnego są dokonywane wydatki w celu oddłużenia s.p.z.o.z., dla których podmiotami tworzącymi są minister, centralny organ administracji rządowej albo wojewoda reprezentujący Skarb Państwa. Nie istnieje odrębna regulacja prawna dotycząca spłaty zadłużenia s.p.z.o.z., dla których podmiotami tworzącymi są j.s.t. lub stationes fisci działające w imieniu Skarbu Państwa. W zakresie pokrycia straty netto zakładu oraz przekształcenia albo likwidacji zakładu będą obowiązywały takie same zasady jak w przypadku zakładów, dla których podmiotami tworzącymi są j.s.t.

Brakuje podstaw prawnych do różnicowania sposobu finansowania podmiotów leczniczych działających w formie spółek kapitałowych, w których udziały (akcje) ma Skarb Państwa, ze względu na źródło finansowania lub podmiot je tworzący. Różnice mogą wynikać z przepisów ustawy o finansach publicznych w zakresie ogólnych zasad wydatkowania środków publicznych pochodzących $\mathrm{z}$ budżetu państwa albo budżetów samorządowych. Te uwagi należy również odnieść do finansowania $\mathrm{z}$ budżetu państwa $\mathrm{w}$ formie dotacji celowych lub na podstawie zawartej umowy podmiotów prowadzących działalność leczniczą na zasadach wynikających z działu V u.d.1. ${ }^{34}$

Zakres podmiotowy ubezpieczenia zdrowotnego obejmuje prawie wszystkie grupy społeczne. Istnieją jednak sytuacje, w których świadczeniobiorca nie ma statusu ubezpieczonego (między innymi nie opłaca składki zdrowotnej lub nie jest ona za niego uiszczana). W związku z tym świadczenia zdrowotne udzielane tym świadczeniobiorcom finansowane są $\mathrm{z}$ budżetu państwa $\mathrm{w}$ formie dotacji celowych na podstawie art. 97 ust. 8 u.ś.o.z. Są one przekazywane na rachunek NFZ, który jest odpowiedzialny za ich udzielanie. W formie dotacji celowych finansowane są także świadczenia wysokospecjalistyczne, a także świadczenia udzielane między innymi na podstawie przepisów ustawy o wychowaniu w trzeźwości i przeciwdziałaniu alkoholizmowi, ustawy o przeciwdziałaniu narkomanii ${ }^{35}$ i ustawy o ochronie zdrowia psychicznego ${ }^{36}$.

34 Art. 115 ust. 4 u.d.l. ogranicza jednak zakres podmiotowy beneficjentów dotacji celowych z budżetu państwa udzielanych z przeznaczaniem na remonty i inwestycje, w tym zakup aparatury i sprzętu medycznego. Na tego rodzaju zadania dotację mogą otrzymać zasadniczo spółki kapitałowe, w których Skarb Państwa lub uczelnia medyczna mają udziały albo akcje reprezentujące co najmniej 51\% kapitału zakładowego, a także samodzielne publiczne zakłady opieki zdrowotnej, dla których Skarb Państwa lub uczelnia medyczna są podmiotami tworzącymi. Tego rodzaju ograniczenie nie występuje w odniesieniu do dotacji udzielanych z budżetów samorządowych.

35 Ustawa z dnia 29 lipca 2005 roku o przeciwdziałaniu narkomanii, Dz.U. z 2016 r. poz. 224 ze zm.

36 Ustawa z dnia 19 sierpnia 1994 roku o ochronie zdrowia psychicznego, Dz.U. z 2016 r. poz. $546 \mathrm{ze} \mathrm{zm}$.

Przegląd Prawa i Administracji 115, 2018

(C) for this edition by CNS 
Kolejnym rodzajem wydatków budżetu państwowego na realizację zadań publicznych z zakresu ochrony zdrowia są dotacje przekazywane Narodowemu Funduszowi Zdrowia w celu finansowania działalności Państwowego Ratownictwa Medycznego. Zasady finansowania ratownictwa medycznego w Polsce wynikają z rozdziału VI ustawy o Państwowym Ratownictwie Medycznym ${ }^{37}$ (art. 46-50). W myśl art. 46 ust. 1 u.p.r.m. zadania zespołów ratownictwa medycznego, z wyłączeniem lotniczych zespołów ratownictwa medycznego, są finansowane z budżetu państwa z części, których dysponentami są poszczególni wojewodowie ${ }^{38}$.

\section{WNIOSKI}

Większość podobieństw i różnic $\mathrm{w}$ zakresie konstrukcji prawnej polskich i włoskich źródeł finansowania ochrony zdrowia jest skutkiem przyjęcia określonego modelu ochrony zdrowia. Katalog źródeł finansowania jest zatem determinowany modelem przyjętym przez dane państwo. Odmienny zakres kompetencji z zakresu ochrony zdrowia nałożony na organy władzy publicznej skutkuje odmiennymi zasadami finansowania tego rodzaju zadań. Model Bismarcka i model Beveridge'a z założenia mają zasadniczo różne źródła finansowania systemu. Głównym źródłem finansowania ochrony zdrowia w modelu budżetowym jest budżet państwa lub budżety jednostek samorządu terytorialnego, natomiast w modelu ubezpieczeniowym - składka na ubezpieczenie zdrowotne.

W związku z tym pomiędzy badanymi katalogami źródeł finansowania ochrony zdrowia występują zasadnicze różnice. Głównym organem odpowiedzialnym za organizację i finansowanie polskiego systemu ochrony zdrowia jest Narodowy Fundusz Zdrowia, którego głównym przychodem są wpływy z tytułu pobierania składki na ubezpieczenie zdrowotne. Włoski ustawodawca zrezygnował z ubezpieczeniowego systemu finansowania ochrony zdrowia. W świetle obecnie obowiązujących przepisów we włoskim modelu zdrowotnym nie ma składki ubezpieczeniowej, która jest głównym źródłem finansowania polskiego systemu ochrony zdrowia. Zastąpiono ją nowymi dochodami podatkowymi, z których wpływy zabezpieczają materialnie realizację zadań publicznych w zakresie ochrony zdrowia.

Zasadniczą różnicą między włoskim a polskim katalogiem źródeł finansowania ochrony zdrowia jest obowiązek partycypowania przez pacjentów w kosz-

37 Ustawa z dnia 8 września 2006 roku o Państwowym Ratownictwie Medycznym, Dz.U. z 2016 r. poz. 1868 ze zm., dalej: u.p.r.m.

38 Zadania lotniczych zespołów ratownictwa medycznego są natomiast finansowane z części budżetu państwa, której dysponentem jest minister zdrowia (art. 48 ust. 1 u.p.r.m.). Finansowanie zadań zespołów lotniczych nie odbywa się z zastosowaniem prawnej formy dotacji. W tym przypadku odpowiadający za ich finansowanie jest minister właściwy do spraw zdrowia. Do jego obowiązków należy przede wszystkim zawieranie umów z dysponentami lotniczych zespołów ratownictwa medycznego. 
tach funkcjonowania systemu zdrowotnego we Włoszech poprzez uiszczanie opłat w zamian za otrzymanie określonego rodzaju świadczenia. Główne źródła finansowania Narodowej Służby Zdrowia we Włoszech mają charakter publicznoprawny. Model finansowania jest bowiem oparty na środkach publicznych pochodzących z budżetu państwa oraz budżetów poszczególnych regionów. Nie bez znaczenia pozostają jednak wpływy z tytułu opłat pobieranych od świadczeniobiorców w związku z udzielaniem świadczeń zdrowotnych określonego rodzaju. W Polsce nie istnieje obowiązek finansowania przez świadczeniobiorców świadczeń przysługujących w ramach publicznego systemu ochrony zdrowia. Nie są oni także zobowiązani do ich współfinansowania. Opłaty uiszczane przez pacjentów w większości przypadków dotyczą sytuacji, w których świadczenia udzielane są poza publicznym systemem i mają charakter prywatnoprawny.

Włoski system ochrony zdrowia jest zdecentralizowany. W związku z tym regiony włoskie zostały obciążone obowiązkiem organizacji i finansowania świadczeń zdrowotnych na swoim terytorium. W związku z przyznaniem im autonomii w przedmiocie finansowania Narodowej Służby Zdrowia powstał system ochrony zdrowia, którego podstawą funkcjonowania są modele regionalne. Zakres dokonywania wydatków publicznych pochodzących z budżetów regionów jest zdecydowanie bardziej rozbudowany niż katalog wydatków dokonywanych przez polskie j.s.t. w celu realizacji nałożonych na nie zadań z zakresu ochrony zdrowia. Skutkiem nałożenia na włoskie regiony obowiązków z zakresu organizacji ochrony zdrowia, w tym udzielania świadczeń zdrowotnych, była konieczność przeniesienia na nie odpowiedzialności za finansowanie systemu ochrony zdrowia.

Wprowadzenie przez polskiego ustawodawcę modelu ochrony zdrowia opartego na metodzie ubezpieczeniowej wpływa na zmniejszenie zakresu przedmiotowego wydatków j.s.t. przeznaczanych na finansowanie systemu. W związku z tym rola budżetów samorządowych w polskim systemie zdrowotnym powinna być odmienna od roli ich włoskich odpowiedników. Wydatki pochodzące z budżetów polskich j.s.t. przeznaczane są głównie na tworzenie i prowadzenie podmiotów leczniczych oraz na fakultatywne finansowanie wykonywanych przez nie zadań (na przykład poprzez udzielenie dotacji), a także na finansowanie gwarantowanych świadczeń zdrowotnych. Zakres dokonywania wydatków jest zatem ograniczony w porównaniu z wydatkami dokonywanymi przez włoskie regiony. Ciężar organizacji i finansowania ochrony zdrowia ponoszą organy administracji samorządowej na poziomie regionów. W związku z tym budżety regionów są głównym źródłem finasowania zadań w tym zakresie. Jest to uzasadnione przyjętym we Włoszech budżetowym modelem finansowania ochrony zdrowia. Polski system nie opiera się na budżetowej metodzie finansowania, a mimo to wydatki budżetów jednostek samorządu terytorialnego zajmują istotne miejsce w jego strukturze.

System ochrony zdrowia w Polsce nie jest w pełni modelem ubezpieczeniowym. Jest on jedynie oparty na ubezpieczeniowej metodzie finansowania. W związku istnieje możliwość wskazania co najmniej nieznacznych podobieństw 
zachodzących między źródłami finansowania ochrony zdrowia w Polsce i we Włoszech. Podobieństwa są skutkiem tego, że w obu systemach jako źródła finansowania wskazuje się budżet państwa oraz budżety samorządowe. Budżet państwa w polskim i włoskim modelu ochrony zdrowia nie stanowi źródła finansowania o zasadniczym znaczeniu. Zakres dokonywanych z niego wydatków na ten cel w Polsce i we Włoszech jest znacznie mniejszy w porównaniu do pozostałych obowiązujących źródeł finansowania.

Źródła finansowania ochrony zdrowia o charakterze publicznoprawnym zostały skonstruowane w Polsce i we Włoszech sposób odmienny, o czym mogą świadczyć wskazane różnice. Uzasadnione wydaje się zatem twierdzenie, że nie jest możliwe przejęcie rozwiązań legislacyjnych stanowiących podstawy funkcjonowania i finansowania włoskiego systemu ochrony zdrowia bez uwzględnienia specyfiki krajowego porządku prawnego.

W świetle dokonanych ustaleń można jednak sformułować wnioski de lege ferenda. Jednostki samorządu terytorialnego w Polsce są zobowiązane do finansowania zadłużenia s.p.z.o.z., które jest powszechnie występującym zjawiskiem. Budżety j.s.t. ponoszą negatywne konsekwencje niedofinansowania świadczeń zdrowotnych udzielanych przez zakłady w ramach umowy zawartej z Narodowym Funduszem Zdrowia. W większości przypadków sytuacja finansowa s.p.z.o.z. nie jest konsekwencją działań organów samorządowych. Mimo to j.s.t. są zobowiązane do finansowania działalności zadłużonych zakładów, a w konsekwencji są zmuszane przez ustawodawcę do faktycznego partycypowania w kosztach udzielania świadczeń zdrowotnych w ramach powszechnego ubezpieczenia zdrowotnego.

$\mathrm{Na}$ gruncie zasad finansowania systemu ochrony zdrowia z włoskiego budżetu centralnego istnieje możliwość pozyskania przez region środków publicznych pochodzących $\mathrm{z}$ tego zasobu finansowego w przypadku powstania deficytu w sektorze zdrowotnym i wdrożenia tak zwanego planu wyrównawczego w celu jego likwidacji. Na wzór rozwiązań włoskich można zatem rozważyć możliwość współfinansowania $z$ budżetu państwa wydatków na pokrycie straty netto zadłużonych zakładów oraz wydatków przeznaczanych na spłatę ich zobowiązań (w przypadku likwidacji bądź przekształcenia s.p.z.o.z.). Przyjmując, że j.s.t. w większości przypadków nie ponoszą odpowiedzialności za powstanie zadłużenia zakładów, dla których są podmiotami tworzącymi, należy podkreślić, że w celu spłaty zadłużenia organy j.s.t. powinny dysponować środkami publicznymi innymi niż przekazane im konstytucyjnie i ustawowo dochody własne. Sposobem rozwiązania problemu finansowania zadłużenia s.p.z.o.z. mogłoby być wprowadzenie możliwości udzielania z budżetu państwa dotacji celowych przeznaczanych przez j.s.t. na realizację tego rodzaju przedsięwzięćc ${ }^{39}$. Jest to jednak uwarunkowane preferencjami usta-

39 Możliwość ubiegania się przez j.s.t. o udzielenie dotacji w związku z zadłużeniem s.p.z.o.z. miała miejsce w polskim porządku prawnym. Mogła być jednak przeznaczona tylko na spłatę zadłużenia zlikwidowanego zakładu i udzielana była do końca 2013 roku (art. 196-203 u.d.1.). 
wodawcy w zakresie kierunków wydatkowania środków publicznych pochodzących z budżetu państwa.

W ocenie autora niniejszego opracowania nie jest jednak możliwe całkowite recypowanie rozwiązań prawnych w zakresie organizacji i finansowania ochrony zdrowia we Włoszech, w tym przekształcenie polskiego modelu zdrowotnego w model budżetowy oparty na środkach publicznych pochodzących z budżetów poszczególnych j.s.t.

Zgodnie z art. 68 ust. 2 Konstytucji RP obywatelom, niezależnie od ich sytuacji materialnej, władze publiczne zapewniają równy dostęp do świadczeń opieki zdrowotnej finansowanej ze środków publicznych. W powołanym przepisie została zatem wyrażona zasada równego dostępu do świadczeń zdrowotnych. W przypadku wprowadzenia modelu samorządowego konieczne byłoby zabezpieczenie środków publicznych, które gwarantowałyby mieszkańcom poszczególnych j.s.t. równy dostęp do świadczeń zdrowotnych niezależnie od ich zdolności dochodowej. Wydaje się, że nie mogłoby się to odbyć poprzez ustawowe przekazanie j.s.t. nowych dochodów własnych. Nie mają one bowiem jednakowej wysokości w odniesieniu do każdej j.s.t. Jednym z rozwiązań byłoby wprowadzenie mechanizmów finansowania samorządowych systemów ochrony zdrowia ze środków publicznych pochodzących z budżetu państwa. W takiej sytuacji budżet państwa zamiast budżetów j.s.t. stałby się głównym źródłem finansowania całego systemu. Nie można byłoby zatem uznać, że jest to przyjęcie rozwiązań legislacyjnych funkcjonujących w szwedzkim systemie ochrony zdrowia.

Obecnie funkcjonujące zasady organizacji i finansowania ochrony zdrowia w Polsce i we Włoszech są skutkiem przeprowadzenia na przestrzeni wielu istotnych reform. Polski ustawodawca zrezygnował z modelu budżetowego opartego na finansowaniu ochrony zdrowia na podstawie ogólnych dochodów budżetowych na rzecz modelu opartego na ubezpieczeniowej metodzie finansowania, którego głównym przychodem są wpływy z tytułu poboru składki na ubezpieczenie zdrowotne. System ochrony zdrowia we Włoszech został natomiast przekształcony z modelu ubezpieczeniowego w model budżetowy opierający się na działalności włoskich regionów. Modyfikacja katalogu źródeł finansowania ochrony zdrowia poprzez rezygnację ze składki na ubezpieczenie zdrowotne nie zlikwidowała jednak problemów włoskiego sektora zdrowotnego. Świadczy o tym przede wszystkim podejmowanie dalszych prób jego reformowania. Powyższą uwagę należy również odnieść do obowiązującego obecnie systemu ochrony zdrowia. Jego przeobrażenia także nie doprowadziły do całkowitej likwidacji problemów w nim występujących. Włoski i polski system ochrony zdrowia jest przykładem tego, że państwa Unii Europejskiej nie są w stanie rozwiązać problemów finansowania opieki zdrowotnej bez względu na przyjęty przez nie teoretyczny model ochrony zdrowia (modele Bismarcka i model Beveridge'a).

W reformach polskiego i włoskiego systemu ochrony zdrowia można dostrzec przejawy przenoszenia coraz większej odpowiedzialności na jednostki 
samorządu terytorialnego. Włoskie i polskie jednostki samorządu terytorialnego są jednak pozbawione wpływu na zasady funkcjonowania systemu oraz kształt podstawowych źródeł finansowania ochrony zdrowia. Nie mają zatem istotnych możliwości pozyskiwania dodatkowych środków w celu zabezpieczenia potrzeb systemu ochrony zdrowia. Muszą natomiast ponosić koszty jego funkcjonowania.

\section{BIBLIOGRAFIA}

Cilione G., Diritto sanitario. Profili constituzionali e amministrativi, ripartizione delle competenze, organizzazione, prestazioni, presidi sanitari privati, professioni, Rimini 2005.

Dirindin N., Federalismo fiscale e tutela della salute. Un percorso di responsabilizzazione della regioni o il pressuposto pre cambiementi strutturali?, [w:] N. Dirindin, E. Pagano, Governare il federalismo. Le sfide della sanità, Milano 2001.

Ferre F., Giulio de Belvis A., Veriano L., Longhi S., Lazzari A., Fattore G., Ricciardi W., Maresso A., Italy. Health system review, „Health System in Transition” 16, 2014, nr 4.

France G., Taroni F., Donatini A., The Italian health-care system, „Health Economics” 2014, nr 14. Innocenti E., Il finanziamento della spesa sanitaria nella recente giurisprudenza costituzionale: tra tutela della salute, coordinamento della finanza pubblica e (in)attuazione dell'art. 119 Cost., „Le Regioni” 2008, nr 36.

Lenio P., Charakter prawny składki na ubezpieczenie zdrowotne jako źródta finansowania świadczeń opieki zdrowotnej, „Przegląd Prawa i Administracji” 2014, nr 97, s. 99-115.

Lenio P., Health insurance contributions of farmers, [w:] Essential Problems with Taxation of Agriculture, red. M. Burzec, P. Smoleń, Lublin 2017, s. 399-412.

Lenio P., Ulgi w zapłacie składki zdrowotnej dla przedsiębiorców, „Prawo Budżetowe Państwa i Samorządu" 2014, nr 2, s. 101-113.

Łyszczarz B., System finansowania opieki zdrowotnej w krajach OECD, „Studia Ekonomiczne Zeszyty Naukowe" 2013, nr 145.

Najwyższa Izba Kontroli (Delegatura w Opolu), Restrukturyzacja wybranych samodzielnych publicznych zakładów opieki zdrowotnej korzystających z pomocy ze środków publicznych (informacja o wynikach kontroli), https://www.nik.gov.pl/kontrole/P/15/092/.

Palladino C., Ordinamento sanitario. Disciplina del Servizio sanitario nazionale, Napoli 2012.

Reviglio F., Health Care and Its Financing in Italy: Issues and Reform Options, „IMF Working Paper" 2000.

Tanner M., The grass is not always greener. A look at Health Care Systems around the world. Italy, „Policy Analysis” 2008, nr 613.

Turati G., The Italian Servizio Sanitario Nazionale: A renewing tale of lost promises, [w:] Federalism and Decentralization in European Health and Social Care, red. J. Costa-Font, S. Greer, New York 2013.

Urbaniak M., Aspekty publicznoprawne organizacji i finansowania ochrony zdrowia w Republice Włoskiej, Toruń 2014.

\section{AKTY PRAWNE}

Decreto legislativo del 30 dicembre 1992, n. 502, Supplemento Ordinario ala Gazzetta Ufficiale del 30 dicembre 1992, n. 305.

Decreto legislativo del 15 dicembre 1997, n. 446, Gazzetta Ufficiale del 23 dicembre 1997, n. 298.

Decreto legislativo del 18 febbraio 2000, n. 56, Gazzetta Ufficiale del 15 marzo 2000 n. 62.

Przegląd Prawa i Administracji 115, 2018

(C) for this edition by CNS 
Decreto legislativo del 6 maggio 2011, n. 68, Gazzetta Ufficiale del 12.05.2011, n. 109.

Legge del 23 dicembre 1978, n. 833; Gazzetta Ufficiale del 28 dicembre 1978, n. 360.

Ustawa z dnia 19 sierpnia 1994 roku o ochronie zdrowia psychicznego (Dz.U. z 2016 r. poz. 546 ze $\mathrm{zm}$.).

Ustawa z dnia 27 sierpnia 2004 roku o świadczeniach opieki zdrowotnej finansowanych ze środków publicznych (Dz.U. z 2016 r. poz. 1793 ze zm.).

Ustawa z dnia 29 lipca 2005 roku o przeciwdziałaniu narkomanii (Dz.U. z 2016 r. poz. 224 ze zm.).

Ustawa z dnia 8 września 2006 roku o Państwowym Ratownictwie Medycznym (Dz.U. z 2016 r. poz. $1868 \mathrm{ze} \mathrm{zm}$.).

Ustawa z dnia 27 sierpnia 2009 roku o finansach publicznych (Dz.U. z 2016 r. poz. 1870 ze zm.).

Ustawa z dnia 15 kwietnia 2011 roku o działalności leczniczej (Dz.U. z 2013 r. poz. 217 ze zm.).

\title{
SOURCES OF FINANCING OF THE HEALTH CARE SYSTEM IN POLAND AND IN ITALY
}

\begin{abstract}
Summary
The study found that the majority of similarities and differences in the legal structure of Polish and Italian sources of financing of health care are the result of the adoption of a specific model of health care, and therefore there are fundamental differences between the catalogues of sources of financing health care in Poland and Italy. The basis for the difference between the Italian and Polish catalogues of sources of financing health care is the obligation of patients to contribute to the costs of the health care system in Italy by paying fees in return for receiving a certain type of service. In the reforms of the Polish and Italian health care systems one can see signs of transferring more and more responsibility to local government units. However, Italian and Polish local government units have no influence on the principles of functioning of the system and the shape of basic sources of financing health care.
\end{abstract}

Keywords: health care, public finances, financing systems 